\title{
THE EFFECT OF THE METHOD OF APPLICATION OF GROWTH REGULATORS ON FRUIT QUALITY OF 'EINSET SEEDLESS' GRAPE (Vitis sp. L.)
}

\author{
Magdalena Kapłan \\ Department of Seed Production and Nurseries, University of Life Sciences in Lublin, Leszczyńskiego 58, 20-068 Lublin, Poland \\ e-mail: magdalena.kaplan@up.lublin.pl
}

Received: 10.02.2011

\begin{abstract}
This study was conducted during the period 2006-2008 in the Faliszowice Vineyard in the Sandomierz Upland. The experiment evaluated yield quality of 'Einset Seedless' grape after the application of gibberellic acid $\left(\mathrm{GA}_{3}\right)$ in the form of the growth regulator Arbostim $100 \mathrm{SL}$ and 2-naphthoxyacetic acid (NOA) in the form of the growth regulator Betokson Super $050 \mathrm{SL}$. These growth regulators were applied during flowering by spraying the inflorescences or immersing them in whole at the following concentrations: $100 \mathrm{mg} \times \mathrm{L}^{-1} \mathrm{GA}_{3}-$ the treatment was performed once at full flowering (70-80\% of open flowers); $50 \mathrm{mg} \times \mathrm{L}^{-1} \mathrm{GA}_{3}$ - the treatment was performed twice: at the beginning of flowering ( $20 \%$ of open flowers), and the second time at the end of flowering ( $80 \%$ of faded flowers); $50 \mathrm{mg} \times \mathrm{L}^{-1} \mathrm{GA}_{3}+0.2 \% \mathrm{NOA}-$ the treatment was performed once at full flowering; and $0.2 \% \mathrm{NOA}$ - the treatment was performed once at full flowering. The study showed that the applied treatments had a beneficial effect on cluster and berry weight as well as on the number of berries per cluster in the grape variety 'Einset Seedless'. Gibberellic acid and the mixture of $50 \mathrm{mg} \times \mathrm{L}^{-1} \mathrm{GA}_{3}$ and $0.2 \%$ NOA were shown to have a significant effect on cluster and berry length; an exception were clusters and berries sprayed with $50 \mathrm{mg} \cdot \mathrm{L}^{-1} \mathrm{GA}_{3}$ whose length did not differ significantly compared to the control ones. The applied treatments slightly affected berry width in the grape variety under study. The growth regulators applied were found to have an adverse effect on extract content in 'Einset Seedless' fruit.
\end{abstract}

Key words: grape, growth regulator, gibberellic acid, 2-natoxyacetic acid

\section{INTODUCTION}

Grapevine growing in Poland is of small economic importance, but great public interest is attached to it and there is a fast increase in crop area. This is attributable, among others, to the fact that in our country it is becoming more and more fashionable to produce wine from grapes grown in your own plantation and it also results from developing enotourism ( $\mathrm{Ka} \mathrm{p} \nmid \mathrm{an}$, 2009; M y śliwi e c, 2009).

In recent years, seedless grapes enjoy great popularity among consumers, but their small size is a problem in their commercialisation (W e a ver, 1976; Halbrooks and Mortensen, 1987; S u rasak and Choopong, 1988; Cas anova et al. 2009; A bu - Z a hra, 2010).

Berry size is affected by both endogenous factors (nutrients and hormonal substances) and exogenous factors (temperature, light, and water availability) (O j e d a et al. 2001; O 11 a t et al. 2002). Endogenous growth stimulators are related to seeds $(\mathrm{Co}$ o m be, 1960; M a y, 2000) whose number is closely correlated with the concentration of this type of compounds (Coo mbe and Hale, 1973; L o o ne y, 1981; La vee and Nir, 1986; Göktürk and Harman$\mathrm{k}$ a y a, 2005).

The role of gibberellins in berry development was described for the first time by C o o m b e (1960). Berry seeds contain high concentrations of gibberellins in the fruit. These high concentrations persist for at least three weeks after bloom, and then they drop to a low level, only to increase again two weeks later; subsequently, their concentration decreases and remains at a low level until the ripening period ( $\mathrm{S}$ c i e $\mathrm{n} \mathrm{z}$ a et al. 1978). An unexpected similar decrease in gibberellins also takes place in the case of seedless grapes (I w a hori et al. 1968; Pére z et al. 2000).

To increase the size of berries and clusters as well as their compactness, gibberellic acid has been used for many years in wine-producing countries: India (Das s and Randhawa, 1968), the USA (Halbrooks and Mortensen, 1987; Lu, 1996), 
Thailand (S u ras ak and Ch o o p ong, 1988), Brazil (Po m m e r, 1995; Formolo et al. 2010), Greece (Korkas et al., 1999), Chile (P ére z and Góm e z, 2000), Spain (C a s a n o v a et al. 2009), Poland (K a p ł a n, 2009), and Jordan (A b u - Z a h r a , 2010). In spite of many experiences and studies, there are no clear guidelines as to rates and the number of applications of these compounds.

According to Myśliwiec (2009), 'Einset Seedless' is the best among all seedless varieties known in Poland that are recommended for soil cultivation, mainly on account of its productivity, frost hardiness, and fruit quality.

The aim of the present study was to evaluate the method of application of gibberellic acid $\left(\mathrm{GA}_{3}\right)$ and 2-naphthoxyacetic acid (NOA) on fruit quality of 'Einset Seedless' grape.

\section{MATERIALS AND METHODS}

This study was conducted during the period 2006-2008 in the Faliszowice Vineyard in the Sandomierz Upland. The experimental material comprised grape vines of the parthenocarpic variety 'Einset Seedless' which were planted in the spring of 2003 at a spacing of $2.0 \times 1.0 \mathrm{~m}\left(5000 \mathrm{pcs} \times \mathrm{ha}^{-1}\right)$ on loess soil. The grape vines were trained to grow up a trellis composed of posts and four metal wires stretched between the posts at the following heights: $70,110,150$, and $190 \mathrm{~cm}$. The plants were pruned in single Guyota style, with the trunk $40 \mathrm{~cm}$ in height, one cane with a length of about $0.9 \mathrm{~m}$, and one two-bud spur.

The experiment was set up in a randomized block design and included 9 treatments with 5 replicates. Replicates were plots in which 3 plants grew.

The experiment evaluated yield quality of 'Einset Seedless' grape after the application of gibberellic acid $\left(\mathrm{GA}_{3}\right)$ in the form of the growth regulator Arbostim $100 \mathrm{SL}$ and 2-naphthoxyacetic acid (NOA) in the form of the growth regulator Betokson Super 050 SL. These growth regulators were applied during flowering by spraying the inflorescences or immersing them in whole (for 2-3 seconds) at the following concentrations: $100 \mathrm{mg} \times \mathrm{L}^{-1} \mathrm{GA}_{3}-$ the treatment was performed once at full flowering (70-80\% of open flowers); $50 \mathrm{mg} \times \mathrm{L}^{-1} \mathrm{GA}_{3}$ - the treatment was performed twice: the first one at the beginning of flowering $(20 \%$ of open flowers), and the second time at the end of flowering (80\% of faded flowers); $50 \mathrm{mg} \times \mathrm{L}^{-1} \mathrm{GA}_{3}+$ $0.2 \% \mathrm{NOA}$ - the treatment was performed once at full flowering (70-80\% of open flowers); and $0.2 \%$ NOA - the treatment was performed once at full flowering (70-80\% of open flowers).

The experiment evaluated yield quality by analysing the following parameters: cluster and berry weight, number of berries per cluster, cluster length, berry length and width as well as extract content. The average cluster weight and length were determined by weighing and measuring 15 typical clusters, with 5 clusters randomly sampled from each plant. The average berry weight, number, length and width were determined by weighing, counting and then measuring berries from five medium-sized clusters from each replicate. Fruit extract content was measured using an Abbe refractometer and determining the percentage content of extract in the juice solution, squeezing the juice out of 20 representative berries from each plant.

The obtained experimental results were statistically analysed using analysis of variance and Tukey's confidence intervals. Statistical inferences were drawn at a significance level of $5 \%$.

\section{RESULTS}

The applied growth regulators were shown to have a beneficial effect on cluster weight in 'Einset Seedless' grape (Table 1). It was found that the plants treated with $50 \mathrm{mg} \times \mathrm{L}^{-1} \mathrm{GA}_{3}$ and the mixture of $50 \mathrm{mg} \times \mathrm{L}^{-1}$ $\mathrm{GA}_{3}+0.2 \%$ NOA, irrespective of application method, as well as with $100 \mathrm{mg} \times \mathrm{L}^{-1} \mathrm{GA}_{3}$ by immersing the flowers, had significantly larger clusters than the control plants. It was observed that the method of application of the growth regulators had a slight effect on the trait in question; the plants treated with $50 \mathrm{mg} \times \mathrm{L}^{-1} \mathrm{GA}_{3}$ and $100 \mathrm{mg} \times \mathrm{L}^{-1} \mathrm{GA}_{3}$ by spraying produced slightly smaller clusters than the immersed ones, while in the case of the other treatments a different situation was observed. The concentration of gibberellic acid and number of treatments were found to have a slight influence on the trait under study, whereas clusters treated with a twice lower concentration had a slightly larger weight than after a single application of the higher rate.

The applied growth regulators had a beneficial effect on the number of berries per cluster (Table 1). The clusters whose inflorescences had been treated with the growth regulators produced more berries per cluster than the control ones. Statistical analysis showed significant differences between the plants whose inflorescences had been treated with $50 \mathrm{mg} \times \mathrm{L}^{-1} \mathrm{GA}_{3}$ and the

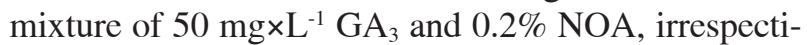
ve of application method, as well as with $100 \mathrm{mg} \times \mathrm{L}^{-1}$ $\mathrm{GA}_{3}$ by immersion, and the control vines. The method of application of the growth regulators tested was not observed to have any clear effect on the number of berries. The concentration of gibberellic acid and number of treatments were found to have a significant influence on the trait in question; the inflorescences sprayed twice with the lower concentration were characterized by a significantly higher number of berries per cluster than after the application of $100 \mathrm{mg} \times \mathrm{L}^{-1} \mathrm{GA}_{3}$. 
Table 1.

Cluster weight, number of berries per cluster, and berry weight depending on the method of application of gibberellic acid $\left(\mathrm{GA}_{3}\right)$ and 2-naphthoxyacetic acid (NOA)

(means for 2006-2008)

\begin{tabular}{llccc}
\hline & \multicolumn{1}{c}{ Treatment } & $\begin{array}{c}\text { Cluster weight, } \\
\mathrm{g}\end{array}$ & $\begin{array}{c}\text { Number of berries } \\
\text { per cluster, } \\
\text { pcs }\end{array}$ & $\begin{array}{c}\text { Berry weight, } \\
\mathrm{g}\end{array}$ \\
\hline 1 & Control & $133.7 \mathrm{~b}$ & $58.7 \mathrm{c}$ & $2.22 \mathrm{~b}$ \\
2 & $50 \mathrm{mg} \times \mathrm{L}^{-1} \mathrm{GA}_{3}-$ spraying & $274.8 \mathrm{a}$ & $116.2 \mathrm{a}$ & $2.47 \mathrm{ab}$ \\
3 & $50 \mathrm{mg} \times \mathrm{L}^{-1} \mathrm{GA}_{3}-$ immersion & $280.0 \mathrm{a}$ & $99.1 \mathrm{ab}$ & $2.51 \mathrm{ab}$ \\
4 & $100 \mathrm{mg} \times \mathrm{L}^{-1} \mathrm{GA}_{3}-$ spraying & $235.5 \mathrm{ab}$ & $76.1 \mathrm{bc}$ & $2.85 \mathrm{a}$ \\
5 & $100 \mathrm{mg} \times \mathrm{L}^{-1} \mathrm{GA}_{3}-$ immersion & $261.0 \mathrm{a}$ & $96.6 \mathrm{ab}$ & $2.61 \mathrm{ab}$ \\
6 & $50 \mathrm{mg} \times \mathrm{L}^{-1} \mathrm{GA}_{3}+0,2 \% \mathrm{NOA}-$ spraying & $271.5 \mathrm{a}$ & $99.0 \mathrm{ab}$ & $2.77 \mathrm{ab}$ \\
7 & $50 \mathrm{mg} \times \mathrm{L}^{-1} \mathrm{GA}_{3}+0,2 \% \mathrm{NOA}-$ immersion & $264.6 \mathrm{a}$ & $97.8 \mathrm{ab}$ & $2.83 \mathrm{ab}$ \\
8 & $0.2 \% \mathrm{NOA}-$ spraying & $174.2 \mathrm{ab}$ & $70.3 \mathrm{bc}$ & $2.25 \mathrm{ab}$ \\
9 & $0.2 \% \mathrm{NOA}-$ immersion & $171.1 \mathrm{ab}$ & $72.3 \mathrm{bc}$ & $2.36 \mathrm{ab}$ \\
\hline
\end{tabular}

Explanation: Means followed by the same letter are not significantly different at $\alpha=0.05$

The applied growth regulators affected beneficially 'Einset Seedless' berry weight (Table 1). The fruits whose inflorescences had been treated with the growth regulators produced slightly heavier berries than the control ones, but these differences were significant only in the case of the plants treated with $100 \mathrm{mg} \times \mathrm{L}^{-1} \mathrm{GA}_{3}$ by spraying the inflorescences. The method of application of the growth regulators was not observed to have any clear effect on the trait in question. The concentration of gibberellic acid and number of treatments were found to have a slight effect on the trait under study; the clusters sprayed twice with the lower concentration were characterized by lower berry weight than after the application of $100 \mathrm{mg} \times \mathrm{L}^{-1} \mathrm{GA}_{3}$.

The length of 'Einset Seedless' grape clusters ranged from 12.9 to $15.8 \mathrm{~cm}$ (Table 2). Gibberellic acid and the mixture of $50 \mathrm{mg} \times \mathrm{L}^{-1} \mathrm{GA}_{3}$ and $0.2 \% \mathrm{NOA}$ were shown to have a significantly beneficial effect on cluster and berry length; an exception were clusters and berries sprayed with $50 \mathrm{mg} \times \mathrm{L}^{-1} \mathrm{GA}_{3}$ whose length did not differ significantly compared to the control ones. The treatment with $0.2 \%$ NOA was found to have an adverse effect on the tested quality parameter. Clusters in the a.m. treatments were slightly shorter than the control ones. The method of application of $\mathrm{GA}_{3}$ and the mixture of $50 \mathrm{mg} \times \mathrm{L}^{-1} \mathrm{GA}_{3}$ and $0.2 \%$ NOA was observed to have a slight influence on cluster length; the inflorescences immersed in the solutions were slightly longer than those sprayed, but these differences were significant only in the case of the treatment with $50 \mathrm{mg} \times \mathrm{L}^{-1} \mathrm{GA}_{3}$.
Average berry length ranged from 15.4 to 19.0 $\mathrm{mm}$ (Table 2). It was found that the application of gibberellic acid and the mixture of $50 \mathrm{mg} \times \mathrm{L}^{-1} \mathrm{GA}_{3}+0.2 \%$ NOA, irrespective of application method, had a beneficial influence on the trait in question. The vines whose inflorescences had been immersed in $50 \mathrm{mg} \times \mathrm{L}^{-1} \mathrm{GA}_{3}$ and treated with $100 \mathrm{mg} \times \mathrm{L}^{-1} \mathrm{GA}_{3}$ and $50 \mathrm{mg} \times \mathrm{L}^{-1} \mathrm{GA}_{3}$ $+0.2 \%$ NOA, irrespective of application method, were found to have significantly longer berries than the control ones. The plants treated with $0.2 \%$ NOA were shown to produce slightly shorter fruits than the control ones. It was observed that in most of the treatments the vines whose inflorescences had been immersed in the tested solutions had slightly longer berries than the sprayed ones, but the plants treated with $0.2 \%$ NOA were an exception. A slight effect of gibberellic acid on the trait in question was observed; the fruits treated with $100 \mathrm{mg} \times \mathrm{L}^{-1} \mathrm{GA}_{3}$ had slightly longer berries than in the case of $50 \mathrm{mg} \times \mathrm{L}^{-1} \mathrm{GA}_{3}$.

In the present study, berry width in 'Einset Seedelss' grape ranged from 13.9 to $15.4 \mathrm{~mm}$ (Table 2). Statistical analysis did not show any significant differences between the fruits whose inflorescences had been treated with the solutions under investigation and the control treatment. The plants treated with $0.2 \%$ NOA were shown to produce slightly narrower berries than the control plants. The tested growth regulators were demonstrated to have a beneficial, but not significant, effect on berry width in the case of the treatments in which $50 \mathrm{mg} \times \mathrm{L}^{-1} \mathrm{GA}_{3}$ was applied by spraying as well as $100 \mathrm{mg} \times \mathrm{L}^{-1} \mathrm{GA}_{3}$ and $50 \mathrm{mg} \times \mathrm{L}^{-1} \mathrm{GA}_{3}+0.2 \%$ NOA, irrespective of application method. 
Table 2.

Berry quality in 'Einset Seedless' grape depending

on the method of application of gibberellic acid $\left(\mathrm{GA}_{3}\right)$ and 2-natoxyacetic acid (NOA)

(means for 2006-2008)

\begin{tabular}{llcccc}
\hline & \multicolumn{1}{c}{ Treatment } & $\begin{array}{c}\text { Cluster length, } \\
\mathrm{cm}\end{array}$ & $\begin{array}{c}\text { Berry length, } \\
\mathrm{mm}\end{array}$ & $\begin{array}{c}\text { Berry width, } \\
\text { mm }\end{array}$ & $\begin{array}{c}\text { Extract } \\
{ }^{\circ} \text { Brix }\end{array}$ \\
\hline 1 & Control & $13.7 \mathrm{~cd}$ & $16.3 \mathrm{bc}$ & $14.5 \mathrm{ab}$ & $18.4 \mathrm{a}$ \\
2 & $50 \mathrm{mg} \times \mathrm{L}^{-1} \mathrm{GA}_{3} / 2-$ spraying & $14.5 \mathrm{bc}$ & $17.4 \mathrm{ab}$ & $14.7 \mathrm{ab}$ & $16.1 \mathrm{~b}$ \\
3 & $50 \mathrm{mg} \times \mathrm{L}^{-1} \mathrm{GA}_{3} / 2-$ immersion & $15.7 \mathrm{a}$ & $18.7 \mathrm{a}$ & $14.5 \mathrm{ab}$ & $16.1 \mathrm{~b}$ \\
4 & $100 \mathrm{mg} \times \mathrm{L}^{-1} \mathrm{GA}_{3}-$ spraying & $15.1 \mathrm{ab}$ & $18.7 \mathrm{a}$ & $15.4 \mathrm{a}$ & $16.2 \mathrm{~b}$ \\
5 & $100 \mathrm{mg} \times \mathrm{L}^{-1} \mathrm{GA}_{3}-$ immersion & $15.5 \mathrm{a}$ & $19.0 \mathrm{a}$ & $15.4 \mathrm{a}$ & $16.4 \mathrm{~b}$ \\
6 & $50 \mathrm{mg} \times \mathrm{L}^{-1} \mathrm{GA}_{3}+0.2 \% \mathrm{NOA} / 1-$ spraying & $15.6 \mathrm{a}$ & $18.5 \mathrm{a}$ & $15.3 \mathrm{ab}$ & $16.3 \mathrm{~b}$ \\
7 & $50 \mathrm{mg} \times \mathrm{L}^{-1} \mathrm{GA}_{3}+0.2 \% \mathrm{NOA} / 1-$ immersion & $15.8 \mathrm{a}$ & $18.8 \mathrm{a}$ & $15.2 \mathrm{ab}$ & $16.9 \mathrm{ab}$ \\
8 & $0.2 \% \mathrm{NOA} / 1-$ spraying & $13.1 \mathrm{~d}$ & $15.4 \mathrm{c}$ & $14.0 \mathrm{ab}$ & $15.9 \mathrm{~b}$ \\
9 & $0.2 \% \mathrm{NOA} / 1-$ immersion & $12.9 \mathrm{~d}$ & $15.4 \mathrm{c}$ & $13.9 \mathrm{~b}$ & $18.2 \mathrm{a}$ \\
\hline
\end{tabular}

Explanation: Means followed by the same letter are not significantly different at $\alpha=0.05$

During the study, the applied growth regulators were observed to affect adversely the fruit extract content in 'Einset Seedless' fruit (Table 2). The fruits treated with the growth regulators were characterized by lower extract content than the control ones. In the

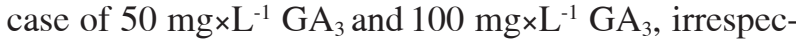
tive of application method, as well as in the case of $50 \mathrm{mg} \times \mathrm{L}^{-1} \mathrm{GA}_{3}+0.2 \% \mathrm{NOA}$ and $0.2 \%$ NOA applied by spraying, these differences were significant. In most of the treatments applied, it was observed that the vines whose inflorescences had been immersed in the solutions under investigation were characterized by slightly higher extract content than the sprayed ones.

\section{DISCUSSION}

In the literature, many recommendations can be found with regard to time and number of treatments as well as the concentration of gibberellic acid. An optimal concentration of $\mathrm{GA}_{3}$ largely depends on weather conditions in a particular growing season and on variety, ranging between 160 and $260 \mathrm{mg} \times \mathrm{L}^{-1} \mathrm{GA}_{3}$ in the case of single application ( $\mathrm{C}$ a s a n o v a et al. 2009). $\mathrm{K}$ ork a s et al. (1999) think that $320 \mathrm{mg} \times \mathrm{L}^{-1} \mathrm{GA}_{3}$ and $650 \mathrm{mg} \times \mathrm{L}^{-1} \mathrm{GA}_{3}$ should be applied to increase 'Sultanina' cluster weight, $\mathrm{Bhujbal}$ and $\mathrm{Chaudhari}$ (1973) recommend the application of $100 \mathrm{mg} \times \mathrm{L}^{-1} \mathrm{GA}_{3}$, whereas D a s s and R a nd haw a (1972) recommend $75 \mathrm{mg} \times \mathrm{L}^{-1} \mathrm{GA}_{3}$ to increase berry weight. All the authors are in agreement that environmental conditions are responsible to the greatest extent for treatment effectiveness. Although there are many studies on the effect of $\mathrm{GA}_{3}$ (L a ve e and Nir, 1986; R o per and Wil li a ms , 1989; Lu et al. 1995; Willi a m s, 1996;
Zabadal and Dittmer, 2000 a, b; Hy unggoo k et al. 2008; Z offoli et al. 2009; A bu-Zahra, 2010), the role of gibberellins on berry growth has not been fully explained.

In fruit and vegetable growing, a mixture of gibberellins with auxins is effectively used to achieve a significant increase in sour cherry, sweet cherry, plum, apple, and tomato yields ( $\mathrm{J}$ a n k i e w i c z, 1997). Treatment of tomato flowers with a mixture of $\mathrm{GA}_{3}$ and NOA contributes to increased yields by $20-60 \%$ and promotes even fruit development.

In the literature, there are many papers (I w a hori et al. 1968; Jankiewicz, 1997; E1-Ghany, 2000; Z a b a d a l and Ditt mer, 2000 b; Fer ree et al. 2004) relating to the beneficial effect of growth regulators on yield and fruit quality in seedless grape varieties.

The study conducted by L u (1996) in an experimental vineyard of the A\&M University, Tallahassee, Florida, in which the effect of gibberellic acid on the quality of 'Orlando Seedless' grapes was evaluated, it was shown that the applied treatments had a beneficial influence on cluster weight. The grape vines treated with $\mathrm{GA}_{3}$ at a rate of $50 \mathrm{mg} \times \mathrm{L}^{-1}$ had slightly larger clusters than the control ones. A significant effect of gibberellic acid on the investigated trait was noted in the case of higher concentrations, i.e.: 100, 150, 200, and

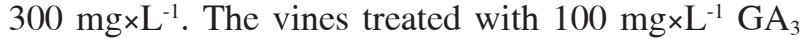
had the largest clusters. However, it was observed that as the concentration increased to 200 and $300 \mathrm{mg} \times \mathrm{L}^{-1}$, cluster weight decreased slightly.

The present study also demonstrated that the applied growth regulators beneficially affected cluster weight in 'Einset Seedless' grape. The method of 
application of the growth regulators was observed to have a slight effect on the trait in question. The plants treated with $50 \mathrm{mg} \times \mathrm{L}^{-1} \mathrm{GA}_{3}$ and $100 \mathrm{mg} \times \mathrm{L}^{-1} \mathrm{GA}_{3}$ by spraying produced slightly smaller clusters than the immersed ones, while in the case of the other treatments a different situation was observed.

The study of L u (1996) showed that the grape vines treated with $\mathrm{GA}_{3}$ produced significantly larger berries than the control ones. The concentration of gibberellic acid was demonstrated to have a significant effect on the trait in question and it was also observed that the concentration of the growth regulator was proportionate to the size of berries obtained. The largest berries were obtained after the application of $300 \mathrm{mg} \times \mathrm{L}^{-1} \mathrm{GA}_{3}$ compared to the control; the fruits in the a.m. treatment were $70 \%$ larger than the control ones. Halbrooks and Mortensen (1987) showed that the concentration and time of application of gibberellic acid significantly affected berry size in seedless varieties. The best effects were achieved after the application of $\mathrm{GA}_{3}$ at a concentration of 75,150 ,

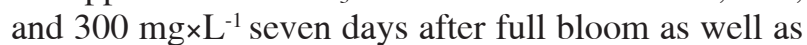

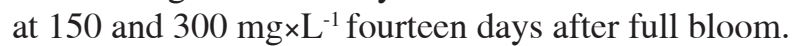

In the present experiment, the applied growth regulators had a beneficial effect on 'Einset Seedless' berry weight. The fruits whose inflorescences had been treated with the growth regulators produced slightly heavier berries than the control ones; these differences were significant in the case of the plants treated with $100 \mathrm{mg} \times \mathrm{L}^{-1} \mathrm{GA}_{3}$ by spraying their inflorescences. There was observed no clear effect of the method of application of the growth regulators on the trait in question.

A similar beneficial effect of gibberellic acid on cluster and berry weight was shown by $\mathrm{S}$ arooshi (1977), K a s i matis et al. (1978), Lavee and N ir (1986), Williams (1996), Zabadal and Dittmer (2000 a, b), Hyung gook et al. (2008), and C a s a nova et al. (2009).

However, the study conducted by Ezzahou a n i et al. (1985) did not show berry weight to increase significantly after the application of gibberellic acid.

The applied growth regulators had a beneficial effect on the number of berries per cluster. In most of the treatments, the plants treated with $\mathrm{GA}_{3}$ and the mixture of $50 \mathrm{mg} \times \mathrm{L}^{-1} \mathrm{GA}_{3}$ and $0.2 \%$ NOA had a higher number of berries per cluster than the control vines. This does not confirm earlier observations of Dokoozlian (1999), Z of foli et al. (2009), and Abu-Zahra (2010) who showed that the application of $\mathrm{GA}_{3}$ increased berry set per cluster compared to the control. As reported by Roper and Williams (1989), the application of $\mathrm{GA}_{3}$ during flowering contributes to a reduction in flowers, while the repeated application after some time significantly affects berry size.
In the present experiment, most of the treatments showed a significant effect of gibberellic acid and the mixture of $50 \mathrm{mg} \times \mathrm{L}^{-1} \mathrm{GA}_{3}$ and $0.2 \% \mathrm{NOA}$ on cluster length in the variety under investigation; an exception were clusters sprayed with $50 \mathrm{mg} \times \mathrm{L}^{-1} \mathrm{GA}_{3}$ whose length did not differ significantly from the control ones. In the experiment conducted by $\mathrm{A} \mathrm{b} \mathrm{u}-\mathrm{Z} \mathrm{a}$ $\mathrm{h} \mathrm{r}$ a (2010), the application of $50 \mathrm{mg} \times \mathrm{L}^{-1} \mathrm{GA}_{3}$ significantly affected cluster length in 'Thomson Seedless' grape. The research carried out by $\mathrm{K}$ a s i m at is and Jen se n (1973) as well as by S u ras a k and Choo p o n g (1988) showed a positive, but not significant, influence of $\mathrm{GA}_{3}$ on cluster length in seedless varieties.

The present study showed a beneficial effect of gibberellic acid and the mixture of $50 \mathrm{mg} \times \mathrm{L}^{-1} \mathrm{GA}_{3}+$ $0.2 \%$ NOA on berry length in 'Einset Seedless' grape. This confirms earlier findings of E $1-\mathrm{B}$ a $\mathrm{n} \mathrm{n}$ and W e a ve r (1979) as well as of S u ras a k and Choo p o n g (1988) who demonstrated a positive influence of gibberellic acid on berry length in seedless varieties. It was observed that the investigated trait was slightly dependent on the concentration of $\mathrm{GA}_{3}$ solution, as the fruits treated with $100 \mathrm{mg} \times \mathrm{L}^{-1}$ had slightly longer berries than in the case of $50 \mathrm{mg} \times \mathrm{L}^{-1}$. A similar correlation was shown by Surasak and Choopong (1988) in evaluating the fruit of the following cultivars: 'Sultana', 'Black Sultana', 'Beauty Seedless', 'Ruby Seedless', 'Delight', 'Early Muscat', and 'Italia', in the case of which a higher concentration of $\mathrm{GA}_{3}$ resulted in a slightly greater berry elongation, but it did not affect significantly the trait in question.

Statistical analysis did not show any significant effect of the applied treatments on 'Einset Seedless' berry width. In the case of most of the treatments, gibberellic acid and the mixture of $50 \mathrm{mg} \times \mathrm{L}^{-1} \mathrm{GA}_{3}+0.2 \%$ NOA had a beneficial influence on the trait under study. This is confirmed by the study of S u ras a k and Ch o op ong (1988) who show a positive, but ambiguous, effect of gibberellic acid on grape fruit width, which was largely dependent on variety. During our investigations, the concentration of gibberellic acid was found to have a slight effect on the trait in question, since the fruits treated with $100 \mathrm{mg} \times \mathrm{L}^{-1} \mathrm{GA}_{3}$ had slightly wider berries than in the case of $50 \mathrm{mg} \mathrm{L}^{-1}$ $\mathrm{GA}_{3}$. A similar correlation was shown by $\mathrm{S} \mathrm{u} \mathrm{ras} \mathrm{ak}$ and Choopong (1988) in the case of the variety 'Ruby Seedless'.

According to Cas an ova et al. (2009), the result of the application of gibberellic acid in seedless varieties at the initial stage of cell growth is that berry weight reaches similar values as in seeded varieties. This also has an effect on the increase in total sugar content and, as a consequence, also increases total water content. Seedless grapes, due to the absence of seeds, do not have an adequate ability to uptake and 
concentrate sugar, as it is the case in seeded varieties. Treatment of seedless berries with $\mathrm{GA}_{3}$ increases sugar uptake and assimilation ( $\mathrm{Z}$ h e $\mathrm{n} \mathrm{m}$ in $\mathrm{g}$ et al. 2008) and, by changing the source of uptake, affects berry development (W u et al. 2001).

The amount of extract accumulated in the fruit is of significant importance in the case of varieties used for wine production and in table varieties. In the grapevine, sugar accumulation begins from the veraison stage (that is, from the time when the berries start to change colour) and continues until the ripening stage ( H r a z din a et al. 1984; P os sner and Kli ever, 1985). The experiment conducted by $\mathrm{C}$ a s o n o v a et al. (2009) showed that 'Emperatiz' seedless berries treated with gibberellic acid had accumulated larger amounts of sugars and water, but this did not contribute to significant differences in osmotic potential and water potential compared to untreated berries. This results from the fact that $\mathrm{GA}_{3}$ has a beneficial effect on cell division and cell enlargement, thus on a higher accumulation of sugars and water without changing pressure potential, which in consequence translates into larger berry and cluster size during harvest (P é re z and Gó m e z, 2000; C a s o n o v a et al. 2009).

In the present experiment during the three-year study period, there was observed no beneficial effect of the applied growth regulators on the level of extract in 'Einset Seedless' grape fruit.

\section{CONCLUSIONS}

1. The applied treatments had a beneficial effect on berry and cluster weight as well as on the number of berries per cluster in 'Einset Seedless' grape.

2. Gibberellic acid and the mixture of $50 \mathrm{mg} \times \mathrm{L}^{-1} \mathrm{GA}_{3}$ and $0.2 \%$ NOA were shown to have a significant effect on 'Einset Seedless' cluster and berry length. An exception were clusters and berries sprayed with $50 \mathrm{mg} \times \mathrm{L}^{-1} \mathrm{GA}_{3}$ whose length did not differ significantly compared to the control ones.

3. The treatments applied slightly affected 'Einset Seedless" berry width.

4. The applied growth regulators were found to have an adverse effect on the extract content in 'Einset Seedelss' fruit.

\section{REFERENCES}

Abu-Zahra T. R., 2010. Berry size of 'Thompson Seedless' as influenced by the application of gibberellic acid and cane girdling. Pak. J. Bot. 42(3): 1755-1760.

Bhujbal B.G., Chaudhari G., 1973. Yield and quality of 'Thompson Seedless' grape (Vitis vinifera L.) as influenced by girdling and gibberellins. Res. J. Mah. Ph. Agric. Univ. 4: 108-112.
Casanova L., Casanova R., Moret A., Agusti M., 2009. The application of gibberellic acid increases berry size of 'Emperatiz' seedless grape. Span. J. Agric. Res. 7(4): 919-927.

Coombe B.G., 1960. Relationship of growth and development to changes in sugars, auxins and gibberellins in fruit of seeded and seedless varieties of Vitis vinifera $\mathrm{L}$. Plant Physiol. 35: 241-250.

Coombe B.G., Hale C.R., 1973. The hormone content of ripening grape berries and the effect of growth substance treatments. Plant Physiol. 51: 629-634.

Das s H.C., R andhawa G.S., 1968. Response of certain seeded Vitis vinifera varieties to gibberellin application at post bloom stage. Amer. J. Enol. Vitic. 19: 56-62.

Dass H.C., Randhawa G.S., 1972. Effect of gibberellic acid on berry enlargement, cluster compactness and yield of 'Pusa Seedless' grape (Vitis vinifera L.). Ind. J. Hort. 29: 158-161.

Dokoozlian N., 1999. Influence of Gibberellic acid berry sizing sprays on Crimson seedless table grape. University of California Cooperative Extension, Tulare County. http://cetulare.ucdavis.edu/pubgrape/tb897.htm.

E1-B a n a G.I., Weaver R. J., 1979. Effect of ethephon and gibberellin on maturation of ungirdled 'Thompson Seedless' grapes. Amer. J. Enol. Vitic. 30: 11-13.

E1-Ghany A.A.A., 2000. Effect of shoot topping, paclobutrazol and gibberellic acid applications on fruit quality of 'Thompson Seedless' grapevines. Ass. J. Agric. Sci. 31 (2): 49-58.

Ezzahouani A.; Lasheen A.M.; Watali L., 1985. Effects of gibberellic acid and girdling on Thompson Seedless and Ruby Seedless table grapes in Morocco. Hortscience, 20, 3: 393- 394.

Ferree D., C., Scurlock D.M., Schmid J.C., 2004. Influence of application time and gibberellic acid concentration on 'Seyval Blanc' grapes. J. Amer. Pomol. Sci. 58 (4): 220-225.

Formolo R., Rufato L., Kretzschmar A.A., Schlemper C., Mendes M., Marcon Filho J.L., Lim a A.P., 2010. Gibberellic acid and cluster thinning on seedless grape 'BRS Clara' in Caxias do Sul, Rio Grande do Sul State, Brazil. Acta Hort. (ISHS) 884: 467-471.

Göktürk N., Harmankaya N., 2005. Changes in endogenous hormone levels during the ripening of grape cultivars having different berry set mechanisms. Turk. J. Agric. For. 29: 205-210.

Halbrooks M.C., Mortensen J.A., 1987. Influence of gibberellic acid and various management practices on berry, seed and cluster development in 'Orland Seedless' grape. Proc. Fla. State Hort. Soc. 100: 312-315.

Hrazdina G., Parsons G.F., Mattick L.R., 1984. Physiological and biochemical events during development and maturation of grape berries. Am. J. Enol. Viticult. 35: 220-227.

Hyunggook K., Donggeun C., Inkyu K., 2008. Effect of growth regulator treatments on quality and 
growth in 'Gailiangmeru' grape (Vitis spp.). Acta Hortic. 772: 319-322.

Iwahori S., Weaver R.J., Pool R.M., 1968. Gibberellinlike activity of berries and seedless 'Tokay' grapes. Plant Physiol. 43: 333-337.

Jankiewicz L.S ., 1997. Regulatory wzrostu i rozwoju roślin. PWN Warszawa, cz.1: 282; cz.2: 289 (in Polish).

Kapłan M., 2009. Wpływ kwasu giberelinowego i kwasu 2-naftoksyoctowego na wielkość i jakość plonu winorośli odmiany 'Einset Seedless'. / The effect of gibberellic acid and 2-naphthoxyacetic acid on fruit yield and quality of 'Einset Seedless' grape. Advances Agric. Sci. Prob. Is. 539: 299-305 (in Polish).

Kasimatis A.N., Jensen F.L., 1973. Growth regulators in grape production. In: M. D. Miller (ed). Study Guide for Agricultural Pest Control Advisers on Plant Growth Regulators. Division of Agricultural Science, University of California. Berkeley. 79.

Kasimatis A.N., Swanson F.H., Vilas jr. E.P., 1978. Effects on bloom applied gibberellic acid on soluble solids and berry weight of 'Thompson Seedless' grapes and on raisin grapes. Amer. J. Enol. Vitic. 29: 263-266

Korkas E., Nerantzis E., Kourtidou-Tymba P., Banilas G., 1999. The effect of gibberellic acid application at different phenological growth stages on yield and quality parameters of 'Sultanina' table grapes (Vitis vinifera L.) in Greece. Part I. At development of flower cluster and at frui set bloomtime. Vitic. Enol. Sci. 54: 44-53.

Lavee S., Nir G., 1986. Grape. In: CRC Handbook of fruit set and development (Monselise S.P., ed). CRC Press, Boca Raton, Florida, USA: 167-191.

L o o n ey N.E., 1981. Some growth regulator and cluster thinning effects on berry set and size, berry quality and annual productivity of the 'Chauna'grapes. Vitis, 20: 22-35.

Lu J., Lamikanra O., Leong S., 1995. Effects of Gibberellic acid on muscandine grape production. Proc. Fla. State Hort. Soc., 108: 360-361.

Lu J., 1996. Application of gibberellic acid on grape cultivar 'Orlando Seedless'. Proc. Fla. State Hort. Soc. 109: 246-247.

M a y P., 2000. From bud to berry, with especial reference to inflorescence and bunch morphology in Vitis vinifera $\mathrm{L}$. Aus. J. Grape. Wine. Res. 6: 82-98.

Myśliwiec R., 2009. Uprawa winorośli. Plantpress, Kraków: 161 (in Polish).

Ojeda H., Deloire A., Carbonneau A., 2001. Influence of water deficits on grape berry growth. Vitis, 40: 141-145.

Ollat N., Diakou-Verdin P., Carde J.P., Barrieu F., Gaudillere J.P., Moing A., 2002. Grape berry development: a review. J. Int. Sci. Vigne. Vin. 36: 109-131.

Pérez F.J., Gómez M., 2000. Possible role of soluble invertase in the gibberellic acid berry-sizing effect in Sultana grape. Plant Growth Regulation, 30: 111-116.
Pérez F.J., Viani C., Retamales J., 2000. Bioactive gibberellins in seeded and seedless grapes: identification and changes in content during berry development. Am. J. Enol. Vitic. 51: 315-318.

Pommer C.V., 1995. Characteristic of seedless grape cv. Maria as affected by girdling and gibberellic acid. Bragantia, 54, 1: 151-159.

Possner D., Kliever W. M., 1985. The localisation of acids, sugars, potassium and calcium in developing grape berries. Vitis, 24: 229-240.

Roper, T.R., Williams L.E., 1989. Net $\mathrm{CO}_{2}$ assimilation and carbohydrate Partitioning of grapevine leaves in response to trunk girdling and Gibberellic acid application. Plant Physiol. 89: 1136-1140.

S arooshi R. A., 1977. Some effects of girdling, gibberellic acid sprays, bunch thinning and timing on the 'Sultana'. Austr. J. Exper. Agric. Ani. Hus. 17 (87): 700-704.

Scienza A., Miravalle C.V., Fregoni M., 1978. Relationships between seed number, gibberellin and abscisic acid levels and ripening in 'Cabernet Sauvignon' grape berries. Vitis 17: 361-368.

Surasak N., Choopong S., 1988. The Improvement of Grape Quality and Production: Fruiting Responses of Some Grape Varieties to Gibberellic Acid. Kasetsart J. Nat. Sci. 22: 229-237.

We a ver R . J., 1976. Grape growing. John Wiley \& Sons Inc, San Francisco, CA, USA: 371.

Willi a m s L.E., 1996. Grape. In: Photoassimilate distribution in plants and crops: Source-sink relationships (Zamski E., Schaffer A.A., eds). Marcel Dekker Inc, NY, USA: 851-881.

Wu J., Zhong J.H., Xu K., Wei Q.P., Wei Z.L., 2001. Effect of exogenous $\mathrm{GA}_{3}$ on fruit development and endogenous hormones in 'Fujiminori' Grape. J. Fruit Sci. 18: 2009-2012.

Zabadal T.J., Howell G.S., Miller D.P., 1997. Table Grapes in Michigan. Extension Bulletin E-2642 New December 1997.

Zabadal T.J., Dittmer T.W., 2000 a. Gibberellic acid sprays increase berry size and reduce shot berry of 'Vanessa' grape - vine. J. Am. Pomol. Soci. 54 (3): 130133.

Zabadal T.J., Dittmer T.W., 2000 b. Influence of gibberellic acid sprays on berry size and shot berry on 'Vanesa' grapevines. Acta Hortic. 527: 153-157.

Zhenming N.,X., Xuefeng W., Yi, L., Tianzhong L., Jin K., Zhenhai H., 2008. Effects of leaf-applied potassium, Gibberellin and Source-Sink Ratio on potassium absorption and distribution in grape fruits. Sci. Hortic. 115: 164-167.

Zoffoli J.P., Latorre B.A., Naranjo P., 2009. Preharvest applications of growth regulators and their effect on postharvest quality of Table Grapes during cold storage. Postharvest Biology and Technology, 51(2): 183-192. 


\section{Wpływ sposobu nanoszenia regulatorów wzrostu na jakość owoców} winorośli (Vitis sp. L.) odmiany 'Einset Seedless'

\section{Streszczenie}

Badania przeprowadzono w latach 2006-2008 w Winnicy Faliszowice na terenie Wyżyny Sandomierskiej. W doświadczeniu oceniano jakość plonu winorośli odmiany 'Einset Seedless' po zastosowaniu kwasu giberelinowego $\left(\mathrm{GA}_{3}\right)$ w postaci preparatu Arbostim $100 \mathrm{SL}$ i kwasu 2-naftoksyoctowego (NOA) w postaci preparatu Betokson Super 050 SL. Regulatory wzrostu nanoszono $\mathrm{w}$ okresie kwitnienia sprayingując kwiatostany lub zanurzając w całości w następujących stężeniach: $100 \mathrm{mg} \times \mathrm{L}^{-1} \mathrm{GA}_{3}$ - zabieg wykonano jednokrotnie podczas pełni kwitnienia (70-80\% rozwiniętych kwiatów), $50 \mathrm{mg} \times \mathrm{L}^{-1} \mathrm{GA}_{3}-$ zabieg wykonano dwukrotnie: pierwszy na początku kwitnienia (20\% rozwiniętych kwiatów), drugi pod koniec fazy kwitnienia (80\% przekwitniętych kwiatów), $50 \mathrm{mg} \times \mathrm{L}^{-1} \mathrm{GA}_{3}+$ $0,2 \%$ NOA - zabieg wykonano jednokrotnie podczas pełni kwitnienia oraz $0,2 \%$ NOA - zabieg wykonano jednokrotnie podczas pełni kwitnienia. Wykazano, że zastosowane zabiegi korzystnie wpłynęły na masę gron i jagód oraz liczbę jagód w gronie winorośli odmiany 'Einset Seedless'. Wykazano istotny wpływ kwasu giberelinowego oraz mieszaniny $50 \mathrm{mg} \times \mathrm{L}^{-1} \mathrm{GA}_{3}$ i $0,2 \%$ NOA na długość gron i jagód, wyjątek stanowiły grona i jagody sprayingiwane $50 \mathrm{mg} \times \mathrm{L}^{-1} \mathrm{GA}_{3}$ których długość nie różniła się istotnie od kontrolnych. Zastosowane zabiegi w nieznacznym stopniu wpłynęły na szerokość jagód winorośli badanej odmiany. Stwierdzono niekorzystny wpływ zastosowanych regulatorów wzrostu na zawartość ekstraktu w owocach odmiany 'Einset Seedless'. 